\title{
The Effect of Vitamin D Deficiency on The Nervous System and Cardiovascular System
} \author{
Hossein Esmaeili*6 \\ ${ }^{1}$ Bachelor of Science in Nursing, Islamic Azad University Tehran Branch, Tehran, Iran \\ ${ }^{2}$ Medical Student,Department of Medicine, Islamic Azad University Tehran Medical Sciences, Tehran, Iran \\ ${ }^{3}$ Young Researcher and Elite Clube, Tehran Medical Sciences, Islamic Azad University, Tehran, Iran \\ ${ }^{4}$ Young Researcher and Elite Clube, Tehran Medical Sciences, Islamic Azad University, Tehran, Iran \\ ${ }^{5}$ Bachelor of Science in Nursing, Islamic Azad University Tehran Branch, Tehran, Iran \\ ${ }^{6}$ Young Researcher and Elite Club, Tehran Medical Sciences, Islamic Azad University, Tehran, Iran
}

Mohammad Yavari ${ }^{1}$, Amirali Jalali Roudsari ${ }^{2}$, Sana Roshani ${ }^{3}$, Soroush Nateghi Far ${ }^{4}$, Nazanin zabihi ${ }^{5}$ and

Submission: January 22, 2021; Published: March 05, 2021

"Corresponding author: Esmaeili H, Young Researcher and Elite Club, Tehran Medical Sciences, Islamic Azad University, Tehran, Iran

\section{Abstract}

Vitamin D is one of the most effective vitamins in the body on the nervous system and cardiovascular system. Its deficiency can be life threatening. Vitamin D deficiency is associated with Adiponectin, LDL, TG, VLDL, HDL. Vitamin D deficiency in the elderly can lead to forgetfulness, depression and mental health problems. In this article, we have a brief and practical overview of the effects of vitamin D on the nervous system and cardiovascular system.

Keywords: Vitamin D deficiency; Cardiovascular system; Nervous system; Blood pressure, Lipoprotein

Abbreviations: CVD: Cardiovascular Disease; CKD: Chronic Kidney Disease; IHD: Ischemic Heart Disease; BP: Blood Pressure; AF: Atrial Fibrillation; TG: Triglyceride; LDL: Low density lipoprotein; VLDL: Very Low-Density Lipoprotein; HDL: High Density Lipoprotein; HCY: Homocysteine; HbA1c: Hemoglobin A1c (glycated hemoglobin); VDR: Vitamin D Receptor; SNP: Single Nucleotide Polymorphism; CCA-IMT: Common Carotid Intimal Medial Thickness; hsCRP: High Sensitivity C-Reactive Protein; PTH: Parathyroid Hormone; MI: Myocardial Infarction; HF: Heart Failure; CRP: C-Reactive Protein; IL: Interleukin; CHD: Coronary Heart Disease; SCD: Sudden Cardiac Death; CAC: Coronary Artery Calcification; SBP: Systolic Blood Pressure; LV: Left Ventricular; UVB: Ultraviolet-B; TC: Total Cholesterol; MPV: Mean Platelet Volume; ERI: Erythropoietin Resistance Index; FMD: Flow Mediated Dilation; AIX: Augmentation index; SEVR: Sub Endocardial Viability Ratio; PWV: Pulse Wave Velocity; RHI: Reactive Hyperemia Index; DRDD2 : Dopamine Receptor D2; MS : Multiple Sclerosis; MS NAWM : MS Normal-Appearing White Matter; ADHD: Attention Deficit Hyperactivity Disorder; MMSE: Mini-Mental State Examination; NAD: Non-Alzheimer Dementia

\section{Introduction}

To date, much research has been done on the mechanism and tissues of the effect of vitamin D, and many experts emphasize on maintaining the natural level of this vitamin in the body.

The heart can be severely affected by vitamin D deficiency, which causes CVD. People with CKD are more likely to develop cardiovascular disease, which researchers believe can help reduce vitamin D intake [1]. Epidemiological findings indicate an increase in mortality due to IHD and BP in patients who are further away from the equator and less exposed to sunlight, resulting in less vitamin D synthesis in their body [2]. Vitamin D deficiency can be treated with Non-Valvular AF [3] and correlation of flow in the coronary arteries [4].

Normal levels of vitamin D are important for the nervous system. Vitamin D deficiency can cause various cancers, including glioma [5]. Vitamin D deficiency has been reported in pregnant women taking anticonvulsant drugs. Also, the percentage of autism in these mothers' infants is higher than others [6]. People with migraines should pay attention to their poor vitamin D levels because its deficiency can be one of the causes of migraines [7].

The skin as a tissue is very important in direct contact with vitamin D. Vitamin D can prevent psoriasis [8]. Extensive research has been conducted on women and men in the United States. The study showed that there was no significant relationship between vitamin D levels and skin cancer as expected [9]. It should be noted that obese people receive less vitamin D [10], which is more exposed to skin risks due to deficiency of this vitamin.

In this article, we review the effects and effects of vitamin D deficiency on the cardiovascular system and nervous system. 


\section{Association of Vitamin D Deficiency with Cardiovascular System}

Some studies on the effect of vitamin D deficiency on CVD have linked this to race. $[11,12]$ For example, an increase in BP in vitamin D deficiency in blacks is half that of whites. [13] Studies have also been performed on gender. Vitamin D intake in men was associated with a reduced risk of CVD, although this was not observed in women [14].

Vitamin D deficiency is associated with obesity [15] and increased TG [16,17] LDL [18], VLDL [19]. However, other studies show these results to be random [10,20-24]. Therefore, vitamin D is associated with the regulation of atherogenic fats and primary markers of CVD [25].

VDR is expressed throughout the vascular system. The calcitriol-VDR complex prevents the proliferation of vascular smooth muscle cells, reduces coagulation, and has antiinflammatory properties. [26] Organic changes in VDR are associated with vitamin D deficiency and are more common in bb genotypes than genotypes. $\mathrm{Bb}$ and $\mathrm{BB}$ are more deficient in vitamin D in Bsml SNP gene and aa genotype than Aa and AA genotypes in Apal SNP gene [27].

Vitamin D deficiency in patients with CKD is associated with inflammation [28] and albuminuria [29]. Patients with CKD have higher levels of CCA-IMT, hsCRP, and CD4 + CD28 + null cells, and there is a strong inverse association between low levels of vitamin $\mathrm{D}$ in these patients and increased factors. It has been reported to be the cause of atherosclerosis in these patients [30].

Vitamin D levels are inversely proportional to PTH levels [31]. Patients with higher PTH levels are at higher risk for CVD, and vitamin D deficiency with secondary hyperparathyroidism can cause CVD [32]. But it was not related to HF but was the opposite in PTH [33]. In some other studies, unlike PTH, vitamin D was not associated with CVD [34].

Severe vitamin D deficiency with high CRP causes CVD, but this effect is not seen for vitamin D alone. Therefore, the association between vitamin D and CVD depends on the inflammatory status [35]. Vitamin D itself plays a role in inflammation with a slight decrease in IL-6 [36]. Vitamins affect the activity and expression of macrophages and lymphocytes in atherosclerotic plaques and cause chronic inflammation of the arterial wall [37].

Vitamin D deficiency is an independent predictor of cardiovascular mortality in ACS patients [38]. Vitamin D deficiency is associated with an increased risk of CAD (not its prevalence) [39] and individuals with vitamin D deficiency are more likely to have coronary artery disease [40]. Vitamin D deficiency is associated with increased risk of HF [41-43], CHD [44], MI [45,46], aortic calcification [47] SCD [48], CAC [49] as well as increased SBP [50]. The effect of vitamin D on IHD $[51,52]$ and AF $[53,54]$ is contradictory. No association was found between vitamin D deficiency and LV diastolic dysfunction and only a slight association was found between vitamin deficiency and interventricular septal thickness [55]. Vitamin D CHD had no effect on secondary cardiovascular events [56]

In patients with metabolic syndrome, the risk of cardiovascular factors increases [57] and vitamin D deficiency is associated with metabolic syndrome [58]. UVB radiation has also been shown to reduce type 2 diabetes by increasing vitamin D levels [59]. However, no other study has shown an association between vitamin D and diabetes [60]. Studies in diabetic patients with vitamin D deficiency have shown weight gain, TC and TG [61] Vitamin D deficiency in these patients was also associated with increased BP and HbA1c. [62] The higher risk of CVD due to vitamin $\mathrm{D}$ deficiency in diabetic patients may be due to inadequate heart regeneration.

Vitamin D has an inverse relationship with MPV [63] and ERI [64] and a direct relationship with hemoglobin [65]. Also, vitamin D deficiency causes less FMD and thus causes Vascular endothelial dysfunction [66,67]. Vitamin D deficiency with arterial stiffness indices (AIX, SEVR, PWV) and arterial function branches (FMD, RHI). Vitamin D deficiency was associated with less SEVR, FMD, and RHI, and more AIX and PWV [68,69]. And an abdomen [70].

The real relationship between the effect of vitamin D and CVD is difficult. One of the reasons for the effect of CVD risk factors on serum vitamin D concentration. For example, weight loss reduces cardiovascular risk factors and at the same time increases the concentration of vitamin D due to reduced fat mass [71].

Some studies have not found vitamin D to be associated with CVD [72]. Other studies have found that vitamin D supplementation has no effect on CVD [73-75]. Other studies have found that vitamin D supplementation has an effect on CVD only in people with vitamin D deficiency. It is considered ineffective in people with normal serum levels of vitamin D [76].

\section{Vitamin D Deficiency Can Cause Severe Disorders of The Nervous System}

Serum levels of vitamin D are generally measured at serum levels of $25(\mathrm{OH}) \mathrm{D}$. The borderline level for vitamin D is $56 \mathrm{nmol}$ / $\mathrm{L}$ in women but $50 \mathrm{nmol}$ / $\mathrm{L}$ in men. Serum levels of Caucasians are higher than serum levels of vitamin D in other breeds. Latitude has no significant effect on serum levels of vitamin D; But the culture of the people of each region is effective based on the way of covering and feeding on their serum vitamin D level [77]. Vitamin D levels in summer compared to winter, younger ages (50-70 years) than older ages (70-87 years), women are different from men, but serum vitamin D levels do not depend on BMI [78]. The use of vitamin D supplements at different ages has different effects on the psychological level of people. The use of vitamin D supplements has no effect on the mental and emotional functioning of adolescents [79]. Taking vitamin D supplements has no effect on mental function and memory in middle-aged people; However, the use of vitamin D supplements and high serum levels of vitamin $25(\mathrm{OH}) \mathrm{D}$, in aging, has a significant effect 
on reducing the risk of Alzheimer's disease and dementia. In older people with higher serum levels of $25(\mathrm{OH}) \mathrm{D}$, they perform better at remembering words than older people with lower levels of 25 $(\mathrm{OH}) \mathrm{D}$, but higher levels of $25(\mathrm{OH}) \mathrm{D}$ in speaking fluently have mental performance. And the depressive state of the elderly has no effect. Elderly people with lower serum levels of $25(\mathrm{OH}) \mathrm{D}$ are more likely to develop amnesia [80]. Vitamin D deficiency affects the genes of mitochondrial, cytoskeletal and synaptic proteins by affecting the genes of intracellular processes and intercell synapses in the brains of adult mice [81]. Taking vitamin D supplements in middle age improves short-term memory but has no effect on the memory factor associated with semantic memory [82]. Among older men and women, people with lower serum levels of vitamin D have slower reaction time, lower endurance, slower gait, and poorer performance-related performance and visual-spatial performance tests. There was no difference in the number of falls between the elderly in the two groups with sufficient serum vitamin D levels and the group with vitamin D deficiency [83]. Elderly people who do not have dementia but have MCI have lower serum concentrations of vitamin D than a group of mentally healthy elderly people. People with higher levels of serum vitamin D are less likely to develop MCI (MCI: Mild Cognitive Impairment) [84]. In the elderly, vitamin D deficiency is seen, as a result of which the brain activities of these people, especially in the field of spatial memory, are less efficient than their peers with sufficient levels of vitamin D [85]. In a group of mice deficient in vitamin $\mathrm{D}$, they had a lower pain threshold than in a control group that received a sufficient vitamin D diet. Vitamin $D$ receptor expression increased at the time of spinal cord injury in both groups, while, as expected, serum $25(\mathrm{OH}) \mathrm{D}$ did not change [86]. Taking vitamin D supplements if the serum concentration of vitamin D is between 50-80 $\mathrm{ng} / \mathrm{ml}$, improves sleep; If the serum concentration of vitamin $\mathrm{D}$ is more than 80 or less than $50 \mathrm{ng}$ per $\mathrm{ml}$, it can cause sleep disorders [87].

The effect of taking vitamin D supplements is that with a 10fold increase in the dose of vitamin $D$, the serum concentration of $25(\mathrm{OH}) \mathrm{D}$ doubles. In the hippocampus of mice with high serum vitamin D levels, the expression of genes involved in cellular communication, synaptic translocation, and G protein-coupled receptor activity is increased [88].

Vitamin D has improved the symptoms of patients with irritable bowel syndrome by affecting the peripheral nervous system, inflammatory processes, and on the other hand, by affecting the central nervous system, the level of anxiety in individuals [89].

Increased expression of vitamin D receptors increases dopamine synthesis by affecting the gene responsible for dopamine packaging and protection; Vitamin D increases dopamine by reducing the expression of DRD2 gene [90].

Vitamin D does not affect the severity of stroke. Vitamin D has an effect on IGF-I, which acts as a neuroprotectant in the stroke ward and improves the post-stroke process [91].

The use of vitamin D supplements in people with migraines reduces the frequency of migraine headaches and the effects that migraine headaches have on the course of life. In people treated with vitamin D supplements, CGRP levels (an important peptide that is higher in people with migraine headaches than in others) were lower than in controls [92].

Numerous results have been obtained in the study of the effect of vitamin D deficiency in the fetal period, from which the opposite can be mentioned. In mice deficient in vitamin $\mathrm{D}$, the interval between bregma and lambda and tyrosine hydroxylase levels, which are involved in the synthesis of dopamine by dopaminergic and adrenergic neurons, is lower than normal due to low tyrosine hydroxylase levels. The number of dopaminergic neurons in the substantia nigra and part of the tegmentum decreases [93]. Mice that were deficient in vitamin D during pregnancy had the same learning as mice that received normal levels of vitamin D during pregnancy, but between 30 and 70 weeks after birth, the hippocampus of the group that received vitamin D during pregnancy They were deficient in vitamin D, had a greater reduction in volume than the other group, and at 30 weeks after birth had a smaller volume of cerebral ventricles than the other group, which disappeared at 70 weeks [94]. Vitamin D deficiency in the fetus leads to changes in the amount of neurotransmitters in different parts of the brain such as increased dopamine, increased noradrenaline in the hippocampus and thalamus and hypothalamus and midbrain, decreased serotonin in the basal ganglia and caudate and putamen, decreased glutamine and glutamate in Different parts of the brain and the increase in serine, glycine and taurine occur only in limited parts of the brain [95].

In female mice deficient in vitamin $\mathrm{D}$, an increase in dopamine transporters is seen in the Putamen, Caudate, and Nucleus accumbens parts of the brain; While there is no difference in other receptors and neurotransmitters in other parts of the brain between mice with normal vitamin D levels and vitamin $\mathrm{D}$ deficiency [96].

1-alpha hydroxylase is one of the enzymes that converts vitamins into active forms in the brain. Expression of this enzyme is found only in the cytoplasm of nerve cells and glia. Vitamin D receptors are present almost exclusively in the nucleus of nerve cells and glia and are not present in the cytoplasm of these cells. Most of the vitamin D receptors are found in the superficial granular layer of the prefrontal part of the cerebral cortex, but in the molecular layer of the prefrontal part of the cerebral cortex. The enzyme 1-alpha hydroxylase is found in greater amounts in the molecular layer of the cerebral cortex and in the superficial granular layer. In the molecular part of the cingulate gingiva, there is a relatively large amount of vitamin D receptors. None of the amygdala parts have a receptor for vitamin D, and the enzyme 1-alpha hydroxylase is moderately expressed in the amygdala. All thalamic nuclei have small or moderate amounts of vitamin D and 
1-alpha hydroxylase receptors, but are abundant in the supraoptic and paraventricular nuclei of the hypothalamus, especially in large cells. Vitamin D receptors are not present in the molecular and porcine layers of the cerebellum, but are abundant in the granular layer. The enzyme 1-alpha hydroxylase is moderately found in the molecular layers and cerebellar Purkinje but is either absent or present in small amounts in many cells of the granular layer [97].

Mutations in the vitamin $\mathrm{D}$ receptor gene in mice cause many changes in behavior, mental function, balance, etc., which are explained below. Vitamin D can affect balance processes by affecting muscles. By causing a mutation in the vitamin D receptor gene and altering the expression of the vitamin $\mathrm{D}$ receptor gene in the balance sections, disturbances in balance at altitude, swimming in a pool that, like other mice, were unable to swim vertically [98]. By mutating the vitamin D receptor gene on one of the mouse chromosomes, the mice did not change their behavior and acted like mice with two healthy vitamin D receptor genes [99].

By deleting the vitamin $\mathrm{D}$ receptor gene in mice, apoptosis in various parts of the brain is dramatically reduced; Including gingival cingulate, dentate, hypothalamic and basal nuclei. Due to the decrease in apoptosis, the number of mitotic cells in these areas increases [100]. vidra and vdrb are two paralogs of vitamin D receptors. In zebrafish, vdrb was removed in larvae by MO injection, which resulted in the removal of Meckel cartilage and palatoquadrate, as well as cartilage hypoplasia. By removing both vdra and vdrb by MO injection, removal of cartilaginous structures of the cranial-series was seen. These findings suggest that VDR expression and signaling are involved in the formation of cranial-serial muscles [101]. Mice that were heterozygous for the lack of the vitamin D receptor gene on one of their chromosomes (heterozygous) showed the same results in depression tests as mice that were homozygous for the vitamin D receptor gene (wild type). Whereas mice homozygously lacked the vitamin D receptor gene (null mutant) showed more depressive behaviors than the other two groups in the same tests [102].

Most people with mental health problems are deficient in vitamin D; Most of these mental problems are in the realm of timing and semantic memory. Older people who are deficient in vitamin D are more likely to develop mental illness [103]. The effect of vitamin D deficiency on mental processes in older mice is greater than that of vitamin D deficiency in young mice; But older mice generally had slower reactions than younger mice. Older mice with normal levels of vitamin D had higher levels of anti-inflammatory cytokines and lower levels of proinflammatory cytokines than older mice deficient in vitamin D; However, both anti-inflammatory and pro-inflammatory cytokines were higher in older mice than in young mice [104], which have a significant effect on the course of the disease in MS [105].

24-OHase is one of the genes affecting the expression of vitamin D receptor, which is most expressed in cerebral cortex cells and parts of the hypothalamus such as periventricular and supraoptic nuclei. In glia cells in the brain, vitamin D receptor expression was seen in both control and MS patients; But in MS NAWM patients, cytoplasmic vitamin D receptor expression was seen, which is not present in the control group. Expression of vitamin D receptors in active affected parts is higher than NAWM. In fact, it appears that the vitamin D receptor mRNA in the affected areas was higher than the vitamin D receptor mRNA in the NAWM MS, which probably indicates the formation of the active 1,25 (OH) 2D form in the affected area and increased tissue response in Has been equivalent to this metabolite [106].

In people with MS who have been on vitamin D supplementation for 6 or 12 months and whose serum levels have increased by $50 \mathrm{nmol} / \mathrm{L}, 57 \%$ less than other people have seen an increase in the number of nerve lesions and a recurrence rate of $27 \%$ The reduction [107] and the volume of T2 lesions [108] were less during the period and had $0.27 \%$ less brain tissue damage [109]. Vitamin D supplementation outside the human body indicates a decrease in IL-17, but in vivo and in the form of high-dose vitamin D supplementation in patients with MS, leads to an increase in IL17 by $60 \%$. Decreases in IL-17 occur in $40 \%$ of individuals, none of whom showed signs of exacerbation of symptoms [110]. Vitamin D supplementation increased TGF-Beta in patients with MS, while there was very little increase in TGF-Beta in the control group. Use of vitamin D supplements in other cytokines including IL-2, IL-4, IL-5, IL-6, IL-9, IL-10, IL-13, IL-17A, INF-gamma and TNF -alfa did not change [111]. Taking high-dose vitamin D supplements over 3 months leads to an increase in serum vitamin D levels, which is positively correlated between vitamin D supplementation and IL10 logarithm [112]. In patients with MS, patients taking vitamin D supplementation did not experience neurological damage to the CNS, whereas in the group taking vitamin D supplementation, neurological damage was observed [113]. The risk of developing MS depends on the mother's serum level of vitamin D during pregnancy; Thus, mothers who have insufficient serum vitamin D levels during pregnancy and are deficient in vitamin D are more likely to develop MS in their children. [114] Serum levels of vitamin D at birth have no effect on the risk of developing MS [115].

The percentage of people with vitamin D deficiency is highest in winter and lowest in summer; This is while in winter, people are more prone to depression than other seasons. Among patients with depression, the percentage of people who are deficient in vitamin D or inadequate levels of vitamin D is higher than people with normal levels of vitamin D. Post-stroke depression is more common in people with vitamin D deficiency [116]. By placing patients with depression treated with vitamin $\mathrm{D}$, the rate of fatigue, insomnia, physical weakness and feelings of depression in these patients is reduced [117]. A group of people who have been or are suffering from depression are more likely to be deficient in vitamin $\mathrm{D}$ than the control group, and people with lower serum levels of vitamin D have experienced longer periods of depression, which is evidence of the effect of concentration and level. Serum 
of vitamin D is on the periods and symptoms of depression [118].

During the 8-week treatment of children with ADHD with vitamin D supplementation in combination with methylphenidate, in the experimental group and methylphenidate supplementation without vitamin D supplementation in the control group, children who took vitamin D supplementation had fewer symptoms in the afternoon than They were in the control group, while the symptoms of morning ADHD were not different between the two groups [119].

Among Swedes, people with autism have lower levels of vitamin D than their siblings who do not have autism. People with autism were more likely to be born in the summer or spring, which had nothing to do with vitamin D levels [120]. In general, the serum level of $25(\mathrm{OH}) \mathrm{D}$ in children with autism is lower than normal, due to which they also have lower serum calcium levels [121]. The use of vitamin D supplements has had a positive effect on improving the symptoms of autism in children; Especially if this supplement is used at a younger age [122]. 2 months after stopping taking vitamin D supplements, the symptoms of the disease in these children worsened, and with continued vitamin D supplementation, their symptoms improved again. In patients with autism, serum levels of $25(\mathrm{OH})$ vitamin D are lower than normal serum levels. One way to improve the symptoms of autism is to take vitamin D so that its serum level reaches at least $40 \mathrm{ng} /$ $\mathrm{ml}$; If the serum level of vitamin D is lower, the therapeutic effects of vitamin D will not be observed [123].

Taking a daily supplement of 2000 IU in the first year of life reduces the risk of schizophrenia in men by $77 \%$ in adulthood, but such an effect has not been observed in women and other mental illnesses [124]. Schizophrenia, treatment with vitamin D supplementation for 8 weeks, did not change the psychological symptoms and metabolic parameters compared to the control group [125] Among people with schizophrenia, patients with lower levels of vitamin D, more severe negative symptoms and neurological function - Show a weaker cognition [126]. There is an inverse relationship between the risk of schizophrenia and fetal vitamin D levels; Vitamin D deficiency in the fetus increases the risk of schizophrenia. Surprisingly, people with maximal serum vitamin D levels during pregnancy are more likely to develop schizophrenia than fetuses with normal vitamin D serum levels [127].

People with inadequate vitamin D levels or vitamin D deficiency are more likely to have dementia, cognitive decline, and Alzheimer's disease $[128,129]$. There is no difference in spatial learning between mice with Alzheimer's with a normal diet and with vitamin D supplementation; However, spatial learning was poorer in the group of mice with Alzheimer's disease and on a diet deficient in vitamin D than in the other groups [130]. Taking mematine with vitamin D supplements in Alzheimer's patients improves their mental abilities in MMSE, while taking mematine or vitamin D supplement alone does not affect people's mental abilities [131].

Older people with a serum level of $25(\mathrm{OH}) \mathrm{D}$ borderline or lower lip are more likely to develop NAD. The onset of NAD is not related to the serum level of vitamin D in individuals. (NAD is actually a mental disorder associated with the destruction of the subcortical area, of which Parkinson's is a type of NAD [132].

Serum levels of $25(\mathrm{OH})$ D in patients with Parkinson's and Alzheimer's are lower than normal. Serum levels of vitamin D in patients with Parkinson's are even lower than serum levels of vitamin D in patients with Alzheimer's disease [133].

People with serum levels of $25(\mathrm{OH}) \mathrm{D}$ are lower than normal levels are more likely to develop Parkinson's, which is associated with a higher level of serum $(\mathrm{OH}) \mathrm{D}$; Thus, people with a serum level of vitamin D of $50 \mathrm{nmol} / \mathrm{L}$ are $65 \%$ less likely to develop Parkinson's disease than people with a serum level of vitamin D of $25 \mathrm{nmol} / \mathrm{L}$ [134]. There are differences between the genotypes of people with Parkinson's disease and healthy people, so that in patients with Parkinson's disease, the frequency of CC + CT replication in the vitamin $\mathrm{D}$ receptor gene in Fok1 polymorphism is higher than in healthy people in Hungary; Due to the change in the vitamin D receptor gene, it becomes 3 amino acids shorter than normal and thus affects the structure of the vitamin D receptor and its function. But there was no difference in vitamin D receptor gene in Apal, Taql and Bsml [135].

There was no difference in vitamin D receptor gene in Apal and Taql between healthy people with MS [136].

In patients with epilepsy, vitamin D receptors on cells around blood vessels were lower than in healthy individuals, which was accompanied by a deficiency of vitamin D in the serum of patients with epilepsy [137]. In a group homozygously lacking the vitamin D receptor gene. Seizures and epileptic seizures are more frequent than groups that are homozygous for vitamin D receptor gene or heterozygous for vitamin D receptor gene, which indicates the effect of vitamin D receptor on epileptic brain-related processes [138]. Taking vitamin D supplements in people with epilepsy leads to a $40 \%$ reduction in seizures [139].

\section{References}

1. Artaza JN, Mehrotra R, Norris KC (2009) Vitamin D and the cardiovascular system. Clinical Journal of the Amerian Society of Nephrology 4(9): 1515-1522.

2. Judd S, Tangpricha V (2008) Vitamin D deficiency and risk for cardiovascular disease. Circulation 117(4): 503-511.

3. Demir M, Uyan U, Melek M (2004) The effects of vitamin D deficiency on atrial fibrillation. Clinical and applied thrombosis/hemostasis 20(1): 98-103.

4. Mozos I, Marginean O (2015) Links between vitamin D deficiency and cardiovascular diseases. BioMed research international 2015: 109275.

5. Norlin M (2020) Effects of vitamin D in the nervous system: Special focus on interaction with steroid hormone signalling and a possible role in the treatment of brain cancer. Journal of Neuroendocrinology 32(1): e12799. 


\section{Novel Approaches in Drug Designing \& Development}

6. Kočovská E, Fernell E, Billstedt E, Minnis H, Gillberg C (2012) Vitamin D and autism: clinical review. Research in developmental disabilities 33(5): 1541-1550.

7. Ghorbani Z, Togha M, Rafiee P, Ahmadi ZS, Magham RR, et al. (2019) Vitamin D in migraine headache: a comprehensive review on literature. Neurological Sciences 40(12): 2459-2477.

8. Barrea L, Savanelli MC, Di Somma C, Napolitano M, Megna M, et al (2017) Vitamin D and its role in psoriasis: An overview of the dermatologist and nutritionist. Reviews in Endocrine and Metabolic Disorders 18(2): 195-205.

9. Park SM, Li T, Wu S, Li WQ, et al. (2016) Vitamin D intake and risk of skin cancer in US women and men. PloS one 11(8): e0160308.

10. Giovannucci E, Liu Y, Rimm EB, Hollis BW, Fuchs CS, et al. (2006) Prospective study of predictors of vitamin D status and cancer incidence and mortality in men. Journal of the National Cancer Institute 98(7) 451-459.

11. Anderson JL, May HT, Horne BD, Bair TL, Hall NL, et al. (2010) Relation of vitamin D deficiency to cardiovascular risk factors, disease status, and incident events in a general healthcare population. The American journal of cardiology 106(7): 963-968.

12. Patel JV, Chackathayil J, Hughes EA, Webster C, Lip GY, et al. (2013) Vitamin D deficiency amongst minority ethnic groups in the UK: a cross sectional study. International journal of cardiology 167(5): 2172-2176.

13. Harris SS (2011) Does vitamin D deficiency contribute to increased rates of cardiovascular disease and type 2 diabetes in African Americans?. The American journal of clinical nutrition 93(5): 1175S-8S.

14. Sun Q, Shi L, Rimm EB, Giovannucci EL, Hu FB, et al. (2011) Vitamin D intake and risk of cardiovascular disease in US men and women. The American journal of clinical nutrition 94(2): 534-542.

15. Forrest KY, Stuhldreher WL (2011) Prevalence and correlates of vitamin D deficiency in US adults. Nutrition research 31(1): 48-54.

16. Sun H, Long SR, Li X, Ge H, Liu X, et al. (2019) Serum vitamin D deficiency and vitamin $\mathrm{D}$ receptor gene polymorphism are associated with increased risk of cardiovascular disease in a Chinese rural population. Nutrition Research 61: 13-21.

17. Saedisomeolia A, Taheri E, Djalali M, Moghadam AM, Qorbani M (2014) Association between serum level of vitamin D and lipid profiles in type 2 diabetic patients in Iran. Journal of Diabetes \& Metabolic Disorders 13(1): 7.

18. Baker JF, Mehta NN, Baker DG, Toedter G, Shults J, et al (2012) Vitamin D, metabolic dyslipidemia, and metabolic syndrome in rheumatoid arthritis. The American journal of medicine 125(10):1036-e9.

19. Skaaby T (2015) The relationship of vitamin D status to risk of cardiovascular disease and mortality. Dan Med J 62(2): B5008.

20. Ponda MP, Huang X, Odeh MA, Breslow JL, Kaufman HW (2012) Vitamin D may not improve lipid levels: a serial clinical laboratory data study. Circulation 126(3): 270-277.

21. Iqbal AM, Dahl AR, Lteif A, Kumar S (2017) Vitamin D deficiency: a potential modifiable risk factor for cardiovascular disease in children with severe obesity. Children 4(9): 80.

22. Alam U, Najam O, Al-Himdani S, Benoliel S, Jinadev P, et al. (2012) Marked vitamin D deficiency in patients with diabetes in the UK. Biometrics 38: 963-974

23. Kim M, Na W, Sohn C (2013) Correlation between vitamin D and cardiovascular disease predictors in overweight and obese Koreans. Journal of clinical biochemistry and nutrition 52(2): 167-171.

24. Censani M, Hammad HT, Christos PJ, Schumaker T (2018) Vitamin D deficiency associated with markers of cardiovascular disease in children with obesity. Global pediatric health 5: 2333794 X17751773.
25. Faridi KF, Lupton JR, Martin SS, Banach M, Quispe R, et al. (2017) Michos ED. Vitamin D deficiency and non-lipid biomarkers of cardiovascular risk. Archives of medical science: AMS 13(4): 732-737.

26. Shapses SA, Manson JE (2011) Vitamin D and prevention of cardiovascular disease and diabetes: why the evidence falls short. Jama 305(24): 2565-2566.

27. Vélayoudom-Céphise FL, Larifla L, Donnet JP, Maimaitiming S, Deloumeaux J, et al. (2011) Vitamin D deficiency, vitamin D receptor gene polymorphisms and cardiovascular risk factors in Caribbean patients with type 2 diabetes. Diabetes \& metabolism. 37(6): 540-545.

28. Isakova T, Gutiérrez OM, Patel NM, Andress DL, Wolf M, et al. (2011) Vitamin D deficiency, inflammation, and albuminuria in chronic kidney disease: complex interactions. Journal of Renal Nutrition 21(4): 295302

29. Welles CC, Whooley MA, Karumanchi SA, Hod T, Thadhani R, et al (2014) Vitamin D deficiency and cardiovascular events in patients with coronary heart disease: data from the Heart and Soul Study. American journal of epidemiology 179(11): 1279-1287.

30. Yadav AK, Banerjee D, Lal A, Jha V (2012) Vitamin D deficiency, CD4+ CD28null cells and accelerated atherosclerosis in chronic kidney disease. Nephrology 17(6): 575-581.

31. Andıran N, Çelik N, Akça H, Doğan G 92012) Vitamin D deficiency in children and adolescents. Journal of clinical research in pediatric endocrinology 4(1): 25-29.

32. Anderson JL, Vanwoerkom RC, Horne BD, Bair TL, May HT, et al. (2011) Parathyroid hormone, vitamin D, renal dysfunction, and cardiovascular disease: dependent or independent risk factors?. American Heart Journal 162(2): 331-339.

33. Kestenbaum B, Katz R, de Boer I, Hoofnagle A, Sarnak MJ, et al. (2011) Vitamin D, parathyroid hormone, and cardiovascular events among older adults. Journal of the American College of Cardiology 58(14): 1433-1441.

34. Wannamethee SG, Welsh P, Papacosta O, Lennon L, Whincup PH (2014) Elevated parathyroid hormone, but not vitamin D deficiency, is associated with increased risk of heart failure in older men with and without cardiovascular disease. Circulation: Heart Failure 7(5): 732-739.

35. Li Q, Dai Z, Cao Y, Wang L (2019) Association of C-reactive protein and vitamin D deficiency with cardiovascular disease: A nationwide crosssectional study from National Health and Nutrition Examination Survey 2007 to 2008 . Clinical cardiology 42(7): 663-669.

36. Longenecker CT, Hileman CO, Carman TL, Ross AC, Seydafkan S, et al (2012) Vitamin D supplementation and endothelial function in vitamin D deficient HIV-infected patients: a randomized placebo-controlled trial. Antiviral therapy 17(4): 613-621.

37. Galesanu C, Mocanu V (2015) Vitamin D deficiency and the clinical consequences. The Medical-Surgical Journal 119(2): 310-8.

38. Correia LC, Sodré F, Garcia G, Sabino M, Brito M, et al. (2013) Relation of severe deficiency of vitamin D to cardiovascular mortality during acute coronary syndromes. The American journal of cardiology 111(3): 324327.

39. Verdoia M, Schaffer A, Sartori C, Barbieri L, Cassetti E, et al. (2014) Vitamin D deficiency is independently associated with the extent of coronary artery disease. European journal of clinical investigation 44(7): 634-642.

40. Syal SK, Kapoor A, Bhatia E, Sinha A, Kumar S, et al. Vitamin D deficiency, coronary artery disease, and endothelial dysfunction: observations from a coronary angiographic study in Indian patients. J I Cardiol 24(8): 385-389.

41. Ford JA, MacLennan GS, Avenell A, Bolland M, Grey A, et al. (2014) 


\section{Novel Approaches in Drug Designing \& Development}

Cardiovascular disease and vitamin D supplementation: trial analysis, systematic review, and meta-analysis. The American journal of clinical nutrition 100(3): 746-755.

42. Thomas GN, ó Hartaigh B, Bosch JA, Pilz S, Loerbroks A, et al. (2012) Vitamin D levels predict all-cause and cardiovascular disease mortality in subjects with the metabolic syndrome: the Ludwigshafen Risk and Cardiovascular Health (LURIC) Study. Diabetes care 35(5): 1158-1164.

43. Gotsman I, Shauer A, Zwas DR, Hellman Y, Keren A, et al. (2012) Vitamin $\mathrm{D}$ deficiency is a predictor of reduced survival in patients with heart failure; vitamin D supplementation improves outcome. European journal of heart failure 14(4): 357-366.

44. Lavie CJ, DiNicolantonio JJ, Milani RV, O'Keefe JH (2013) Vitamin D and cardiovascular health. Circulation 128(22): 2404-2406.

45. Aleksova A, Belfiore R, Carriere C, Kassem S, La Carrubba S, et al. (2015) Vitamin D deficiency in patients with acute myocardial infarction: an Italian single-center study. Int J Vitam Nutr Res 85(1-2): 23-30.

46. Karur S, Veerappa V, Nanjappa MC (2014) Study of vitamin D deficiency prevalence in acute myocardial infarction. IJC Heart \& Vessels 3: 57-59.

47. Căpușa C, Stefan G, Stancu S, Ilyes A, Dorobanţu N, et al. (2016) Subclinical cardiovascular disease markers and vitamin $\mathrm{D}$ deficiency in non-dialysis chronic kidney disease patients. Archives of medical science: AMS 12(5): 1015-1022.

48. Drechsler C, Pilz S, Obermayer-Pietsch B, Verduijn M, Tomaschitz A et al. (2010) Vitamin D deficiency is associated with sudden cardiac death, combined cardiovascular events, and mortality in haemodialysis patients. European heart journal 31(18): 2253-2261.

49. Lee S, Ahuja V, Masaki K, Evans RW, Barinas-Mitchell EJ, et al. (2016) A significant positive association of vitamin D deficiency with coronary artery calcification among middle-aged men: for the ERA JUMP study. Journal of the American College of Nutrition 35(7): 614-620.

50. Alkhatatbeh MJ, Abdul-Razzak KK, Khasawneh LQ Saadeh NA (2017) High prevalence of vitamin D deficiency and correlation of serum vitamin D with cardiovascular risk in patients with metabolic syndrome Metabolic Syndrome and Related Disorders 15(5): 213-219.

51. Siadat ZD, Kiani K, Sadeghi M, Shariat AS, Farajzadegan Z, et al. (2012) Association of vitamin D deficiency and coronary artery disease with cardiovascular risk factors. Journal of research in medical sciences: the official journal of Isfahan University of Medical Sciences 17(11): 10521055.

52. Skaaby T, Husemoen LL, Pisinger C, Jørgensen T, Thuesen BH, et al. (2013) Vitamin D status and incident cardiovascular disease and allcause mortality: a general population study. Endocrine 43(3): 618-625.

53. Rienstra M, Cheng S, Larson MG, McCabe EL, Booth SL, et al. (2011) Vitamin D status is not related to development of atrial fibrillation in the community. American heart journal 162(3): 538-541.

54. Zhang Z, Yang Y, Ng CY, Wang D, Wang J, et al. (2016) Meta-analysis of vitamin $\mathrm{D}$ deficiency and risk of atrial fibrillation. Clinical cardiology 39(9): 537-543

55. Pandit A, Mookadam F, Boddu S, Pandit AA, Tandar A, et al. (2014) Vitamin D levels and left ventricular diastolic function. Open Heart 1(1): e000011.

56. Grandi NC, Breitling LP, Vossen CY, Hahmann H, Wüsten B, et al. (2010) Serum vitamin D and risk of secondary cardiovascular disease events in patients with stable coronary heart disease. American heart journa 159(6): 1044-1051

57. Makariou S, Liberopoulos E, Florentin M, Lagos K, Gazi I, et al. (2012) The relationship of vitamin $\mathrm{D}$ with non-traditional risk factors for cardiovascular disease in subjects with metabolic syndrome. Archives of medical science: AMS 8(3): 437-443.
58. Lally J, Gardner-Sood P, Firdosi M, Iyegbe C, Stubbs B, et al. (2016) Clinical correlates of vitamin D deficiency in established psychosis. BMC psychiatry 16(1): 76.

59. Lindqvist PG (2014) On the Possible Link Between Vitamin D Deficiency and Cardiovascular Disease: Should We D-Lighten Our Lives?. Circulation 129(13): e413-414

60. Alhumaidi M, Adnan AG, Dewish M (2013) Vitamin D deficiency in patients with type-2 diabetes mellitus in southern region of Saudi Arabia. Maedica 8(3): 231-236.

61. Kavarić S, Vuksanović M, Božović D, Jovanović M, Jeremić V, et al. (2013) Body weight and waist circumference as predictors of vitamin D deficiency in patients with type 2 diabetes and cardiovascular disease. Vojnosanitetski pregled 70(2): 163-169.

62. Yilmaz H, Kaya M, Sahin M, Delibasi T (2012) Is vitamin D status a predictor glycaemic regulation and cardiac complication in type 2 diabetes mellitus patients?. Diabetes \& Metabolic Syndrome: Clinical Research \& Reviews 6(1): 28-31.

63. Cumhur Cure M, Cure E, Yuce S, Yazici T, Karakoyun I, et al. (2014) Mean platelet volume and vitamin D level. Annals of laboratory medicine 34(2): 98-103.

64. Gracia-Iguacel C, Gallar P, Qureshi AR, Ortega O, Mon C, et al. (2010) Vitamin D deficiency in dialysis patients: effect of dialysis modality and implications on outcome. Journal of Renal Nutrition 20(6): 359-367.

65. Patel NM, Gutiérrez OM, Andress DL, Coyne DW, Levin A, et al. (2010) Vitamin D deficiency and anemia in early chronic kidney disease. Kidney international 77(8): 715-720.

66. Alsuwadia AO, Farag YM, Al Sayyari AA, Mousa DH, Alhejaili FF, et al (2013) Prevalence of vitamin D deficiency in Saudi adults. Saudi Med J 34(8): 814-818.

67. Harris RA, Pedersen-White J, Guo DH, Stallmann-Jorgensen IS, Keeton D, et al. (2011) Vitamin D3 supplementation for 16 weeks improves flow-mediated dilation in overweight African-American adults. American journal of hypertension 24(5): 557-562.

68. Chitalia N, Recio-Mayoral A, Kaski JC, Banerjee D (2012) Vitamin D deficiency and endothelial dysfunction in non-dialysis chronic kidney disease patients. Atherosclerosis 220(1): 265-268.

69. Al Mheid I, Patel R, Murrow J, Morris A, Rahman A, et al. (2011) Vitamin D status is associated with arterial stiffness and vascular dysfunction in healthy humans. Journal of the American College of Cardiology 58(2): 186-192.

70. Van de Luijtgaarden KM, Voûte MT, Hoeks SE, Bakker EJ, Chonchol M, et al. (2012) Vitamin D deficiency may be an independent risk factor for arterial disease. European Journal of Vascular and Endovascular Surgery 44(3): 301-306.

71. Pilz S, Kienreich K, Tomaschitz A, Lerchbaum E, Meinitzer A, et al. (2012) Vitamin D and cardiovascular disease: update and outlook. Scandinavian Journal of Clinical and Laboratory Investigation 72(sup243): 83-91.

72. Schnatz PF, Nudy M, Jiang X, Demko JE, Appt SE. (2015) Vitamin D deficiency and cardiovascular disease in postmenopausal women: contributions from human and nonhuman primate studies. Menopause 22(5): 554-563.

73. Scragg R, Stewart AW, Waayer D, Lawes CM, Toop L, et al. (2017) Effect of monthly high-dose vitamin D supplementation on cardiovascular disease in the vitamin D assessment study: a randomized clinical trial. JAMA cardiology 2(6): 608-616.

74. Manson JE, Cook NR, Lee IM, Christen W, Bassuk SS, et al. (2019) Vitamin D supplements and prevention of cancer and cardiovascular disease. New England Journal of Medicine 380(1): 33-44. 


\section{Novel Approaches in Drug Designing \& Development}

75. Barbarawi M, Kheiri B, Zayed Y, Barbarawi O, Dhillon H, et al. (2019) Vitamin D supplementation and cardiovascular disease risks in more than 83000 individuals in 21 randomized clinical trials: a meta-analysis. JAMA cardiology 4(8): 765-776.

76. Vacek JL, Vanga SR, Good M, Lai SM, Lakkireddy D, et al. (2012) Vitamin D deficiency and supplementation and relation to cardiovascular health. The American Journal of cardiology 109(3): 359-363.

77. Hagenau T, Vest R, Gissel TN, Poulsen CS, Erlandsen M, et al. (2009) Global vitamin D levels in relation to age, gender, skin pigmentation and latitude: an ecologic meta-regression analysis. Osteoporosis international 20(1): 133-140.

78. Seamans KM, Hill TR, Scully L, Meunier N, Andrillo-Sanchez M, Polito A, et al. (2010) Vitamin D status and measures of cognitive function in healthy older European adults. European journal of clinical nutrition 64(10): 1172-1178

79. Dean AJ, Bellgrove MA, Hall T, Phan WM, Eyles DW, et al. (2011) Effects of vitamin D supplementation on cognitive and emotional functioning in young adults-a randomised controlled trial. PloS one 6(11): e25966

80. Fashanu OE, Zhao D, Schneider AL, Rawlings AM, Sharrett AR, et al. (2019) Mid-life serum Vitamin D concentrations were associated with incident dementia but not late-life neuropsychological performance in the Atherosclerosis Risk in Communities (ARIC) Study. BMC neurology 19(1): 244

81. Eyles D, Almeras L, Benech P, Patatian A, Mackay-Sim A, et al. (2007) Developmental vitamin D deficiency alters the expression of genes encoding mitochondrial, cytoskeletal and synaptic proteins in the adult rat brain. The Journal of steroid biochemistry and molecular biology 103(3-5): 538-545.

82. Andreeva VA, Whegang-Youdom S, Touvier M, Assmann KE, Fezeu L, et al. (2014) Midlife dietary vitamin D intake and subsequent performance in different cognitive domains. Annals of Nutrition and Metabolism 65(1): 81-89.

83. Menant JC, Close JC, Delbaere K, Sturnieks DL, Trollor J, et al. (2012) Relationships between serum vitamin D levels, neuromuscular and neuropsychological function and falls in older men and women. Osteoporosis International 23(3): 981-989.

84. Annweiler C, Fantino B, Schott AM, Krolak-Salmon P, Allali G, et al (2012) Vitamin D insufficiency and mild cognitive impairment: crosssectional association. European Journal of Neurology 19(7): 1023 1029.

85. Seamans KM, Hill TR, Scully L, Meunier N, Andrillo-Sanchez M, et al. (2010) Vitamin D status and measures of cognitive function in healthy older European adults. European journal of clinical nutrition 64(10): 1172-1178.

86. Guida F, Boccella S, Belardo C, Iannotta M, Piscitelli F, et al. (2020) Altered gut microbiota and endocannabinoid system tone in vitamin D deficiency-mediated chronic pain. Brain, behavior, and immunity 85 128-141.

87. Gominak SC, Stumpf WE (2012) The world epidemic of sleep disorders is linked to vitamin D deficiency. Medical hypotheses 79(2): 132-135.

88. Latimer CS, Brewer LD, Searcy JL, Chen KC, Popović J, et al. (2014) Vitamin D prevents cognitive decline and enhances hippocampal synaptic function in aging rats. Proceedings of the National Academy of Sciences 111(41): E4359-66

89. Abbasnezhad A, Amani R, Hajiani E, Alavinejad P, Cheraghian B, et al. (2010) Effect of vitamin D on gastrointestinal symptoms and health-related quality of life in irritable bowel syndrome patients: a randomized double-blind clinical trial. Neurogastroenterology \& Motility 28(10): 1533-1544.

90. Pertile RA, Cui X, Eyles DW (2016) Vitamin D signaling and the differentiation of developing dopamine systems. Neuroscience 333: 193-203.
91. Balden R, Selvamani A, Sohrabji F (2012) Vitamin D deficiency exacerbates experimental stroke injury and dysregulates ischemia-induced inflammation in adult rats. Endocrinology 153(5): 2420-2435.

92. Ghorbani Z, Rafiee P, Fotouhi A, Haghighi S, Magham RR, et al. (2020) The effects of vitamin D supplementation on interictal serum levels of calcitonin gene-related peptide (CGRP) in episodic migraine patients: post hoc analysis of a randomized double-blind placebo-controlled trial. The Journal of Headache and Pain 21(1): 22.

93. Hawes JE, Tesic D, Whitehouse AJ, Zosky GR, Smith JT, et al. (2015) Maternal vitamin $\mathrm{D}$ deficiency alters fetal brain development in the BALB/c mouse. Behavioural brain research 286: 192-200.

94. de Abreu DA, Nivet E, Baril N, Khrestchatisky M, Roman F, et al. (2010) Developmental vitamin D deficiency alters learning in $\mathrm{C} 57 \mathrm{Bl} / 6 \mathrm{~J}$ mice. Behavioural brain research 208(2): 603-608.

95. Kesby JP, Turner KM, Alexander S, Eyles DW, McGrath JJ, et al. (2017) Developmental vitamin D deficiency alters multiple neurotransmitter systems in the neonatal rat brain. International Journal of Developmental Neuroscience 62: 1-7.

96. Kesby JP, Cui X, O’Loan J, McGrath JJ, Burne TH, et al. (2010) Developmental vitamin D deficiency alters dopamine-mediated behaviors and dopamine transporter function in adult female rats. Psychopharmacology 208(1): 159-168

97. Eyles DW, Smith S, Kinobe R, Hewison M, McGrath JJ (2005) Distribution of the vitamin $\mathrm{D}$ receptor and $1 \alpha$-hydroxylase in human brain. Journal of chemical neuroanatomy 29(1): 21-30.

98. Minasyan A, Keisala T, Zou J, Zhang Y, Toppila E, et al. (2009) Vestibular dysfunction in vitamin D receptor mutant mice. The Journal of steroid biochemistry and molecular biology 114(3-5): 161-166.

99. Kalueff AV, Lou YR, Laaksi I, Tuohimaa P (2004) Impaired motor performance in mice lacking neurosteroid vitamin $D$ receptors. Brain research bulletin 64(1): 25-29.

100. Ko P, Burkert R, McGrath J, Eyles D (2004) Maternal vitamin D3 deprivation and the regulation of apoptosis and cell cycle during rat brain development. Developmental Brain Research 153(1): 61-68.

101. Kwon HJ (2019) Vitamin D Receptor Signaling Regulates Craniofacial Cartilage Development in Zebrafish. Journal of developmental biology $7(2): 13$.

102. Kalueff AV, Lou YR, Laaksi I, Tuohimaa P (2004) Increased anxiety in mice lacking vitamin D receptor gene. Neuroreport 15(8): 12711274.

103. Annweiler C, Milea D, Whitson HE, Cheng CY, Wong TY, et al. (2016) Vitamin D insufficiency and cognitive impairment in Asians: a multiethnic population-based study and meta-analysis. Journal of internal medicine 280(3): 300-311.

104. Briones TL, Darwish H (2012) Vitamin D mitigates age-related cognitive decline through the modulation of pro-inflammatory state and decrease in amyloid burden. Journal of neuroinflammation 9(1): 244

105. Rolf L, Smolders J, van den Ouweland J, Hupperts R, Damoiseaux J (2019) Correlation of different cellular assays to analyze T cell-related cytokine profiles in vitamin D3-supplemented patients with multiple sclerosis. Molecular immunology 105: 198-204.

106. Smolders J, Schuurman KG, Strien ME, Melief J, Hendrickx D, et al. (2013) Expression of vitamin D receptor and metabolizing enzymes in multiple sclerosis-affected brain tissue. Journal of Neuropathology \& Experimental Neurology 72(2): 91-105.

107. Mowry EM, Waubant E, McCulloch CE, Okuda DT, Evangelista AA, et al. (2012) Vitamin D status predicts new brain magnetic resonance imaging activity in multiple sclerosis. Annals of neurology $72(2)$ : 234-240. 


\section{Novel Approaches in Drug Designing \& Development}

108. Fitzgerald KC, Munger KL, Köchert K, Arnason BG, Comi G, et al (2015) Association of vitamin D levels with multiple sclerosis activity and progression in patients receiving interferon beta-1b. JAMA neurology 72(12): 1458-1465.

109. Ascherio A, Munger KL, White R, Köchert K, Simon KC, et al. (2014) Vitamin $\mathrm{D}$ as an early predictor of multiple sclerosis activity and progression. JAMA neurology 71(3): 306-314.

110. Toghianifar N, Ashtari F, Zarkesh-Esfahani SH, Mansourian M (2015) Effect of high dose vitamin D intake on interleukin-17 levels in multiple sclerosis: a randomized, double-blind, placebo-controlled clinical trial. Journal of neuroimmunology 285: 125-128.

111. Åivo J, Hänninen A, Ilonen J, Soilu-Hänninen M (2015) Vitamin D3 administration to MS patients leads to increased serum levels of latency activated peptide (LAP) of TGF-beta. Journal of Neuroimmunology 280: $12-5$.

112. Ashtari F, Toghianifar N, Zarkesh-Esfahani SH, Mansourian M (2015) Short-term effect of high-dose vitamin D on the level of interleukin 10 in patients with multiple sclerosis: a randomized, double-blind placebo-controlled clinical trial. Neuroimmunomodulation 22(6) 400-404.

113. Shaygannejad V, Janghorbani M, Ashtari F, Dehghan H (2012) Effects of adjunct low-dose vitamin d on relapsing-remitting multiple sclerosis progression: preliminary findings of a randomized placebo-controlled trial. Multiple sclerosis international 2012: 452541.

114. Munger KL, Åivo J, Hongell K, Soilu-Hänninen M, Surcel HM, et al. (2016) Vitamin D status during pregnancy and risk of multiple sclerosis in offspring of women in the Finnish maternity cohort. JAMA neurology 73(5): 515-519.

115. Ueda P, Rafatnia F, Bäärnhielm M, Fröbom R, Korzunowicz G, et al. (2014) Neonatal vitamin D status and risk of multiple sclerosis. Annals of neurology 76(3): 338-346.

116. Gu Y, Zhu Z, Luan X, He J (2019) Vitamin D status and its association with season, depression in stroke. Neuroscience Letters. 690: 99-105

117. Högberg G, Gustafsson SA, Hällström T, Gustafsson T, Klawitter B, et al. (2012) Depressed adolescents in a case-series were low in vitamin $\mathrm{D}$ and depression was ameliorated by vitamin D supplementation. Acta Paediatrica 101(7): 779-783.

118. Milaneschi Y, Hoogendijk W, Lips PT, Heijboer AC, Schoevers R, et al (2014) The association between low vitamin D and depressive disorders. Molecular psychiatry 19(4):444-451.

119. Mohammadpour N, Jazayeri S, Tehrani-Doost M, Djalali M, Hosseini $M$, et al. (2008) Effect of vitamin D supplementation as adjunctive therapy to methylphenidate on ADHD symptoms: A randomized, double blind, placebo-controlled trial. Nutritional Neuroscience 21(3): 202-209.

120. Fernell E, Bejerot S, Westerlund J, Miniscalco C, Simila H, et al. (2015) Autism spectrum disorder and low vitamin D at birth: a sibling control study. Molecular Autism 6(1):3

121. Meguid NA, Hashish AF, Anwar M, Sidhom G (2010) Reduced serum levels of 25-hydroxy and 1, 25-dihydroxy vitamin D in Egyptian children with autism. The Journal of Alternative and Complementary Medicine 16(6): 641-645.

122. Feng J, Shan L, Du L, Wang B, Li H, et al. (2017) Clinical improvement following vitamin D3 supplementation in autism spectrum disorder. Nutritional neuroscience 20(5): 284-290

123. Jia F, Shan L, Wang B, Li H, Feng J, et al. (2019) Fluctuations in clinical symptoms with changes in serum $25(\mathrm{OH})$ vitamin D levels in autistic children: Three cases report. Nutritional neuroscience 22(12): 863866.
124. McGrath J, Saari K, Hakko H, Jokelainen J, Jones P, et al. (2004) Vitamin D supplementation during the first year of life and risk of schizophrenia: a Finnish birth cohort study. Schizophrenia research 67(23): $237-245$

125. Krivoy A, Onn R, Vilner Y, Hochman E, Weizman S, et al. (2017) Vitamin D supplementation in chronic schizophrenia patients treated with clozapine: a randomized, double-blind, placebo-controlled clinical trial. EBioMedicine 26: 138-145.

126. Graham KA, Keefe RS, Lieberman JA, Calikoglu AS, Lansing KM, et al (2015) Relationship of low vitamin D status with positive, negative and cognitive symptom domains in people with first-episode schizophrenia. Early intervention in psychiatry 9(5): 397-405.

127. McGrath JJ, Burne TH, Féron F, Mackay-Sim A, Eyles DW (2010) Developmental vitamin D deficiency and risk of schizophrenia: a 10-year update. Schizophrenia bulletin 36(6): 1073-1078.

128. Annweiler C, Rolland Y, Schott AM, Blain H, Vellas B, et al. (2012) Higher vitamin D dietary intake is associated with lower risk of Alzheimer's disease: a 7-year follow-up. Journals of Gerontology Series A: Biomedical Sciences and Medical Sciences 67(11): 1205-1211.

129. Llewellyn DJ, Lang IA, Langa KM, Muniz-Terrera G, Phillips CL, et al. (2010) Vitamin D and risk of cognitive decline in elderly persons. Archives of internal medicine 170(13): 1135-1141.

130. Taghizadeh M, Djazayery A, Salami M, Eshraghian MR, Zavareh SA (2011) Vitamin-D-free regimen intensifies the spatial learning deficit in Alzheimer's disease. International Journal of Neuroscience 121(1): 16-24.

131. Annweiler C, Herrmann FR, Fantino B, Brugg B, Beauchet $O$ (2012) Effectiveness of the combination of memantine plus vitamin $\mathrm{D}$ on cognition in patients with Alzheimer disease: a pre-post pilot study. Cognitive and behavioral neurology 25(3):121-127.

132. Annweiler C, Rolland Y, Schott AM, Blain H, Vellas B, et al. (2011) Serum vitamin $\mathrm{D}$ deficiency as a predictor of incident non-Alzheimer dementias: a 7-year longitudinal study. Dementia and geriatric cognitive disorders 32(4): 273-278.

133. Evatt ML, DeLong MR, Khazai N, Rosen A, Triche S, et al. (2008) Prevalence of vitamin D insufficiency in patients with Parkinson disease and Alzheimer disease. Archives of neurology 65(10): 1348-1352.

134. Knekt P, Kilkkinen A, Rissanen H, Marniemi J, Sääksjärvi K, et al. (2010) Serum vitamin D and the risk of Parkinson disease. Archives of neurology 67(7): 808-811.

135. Török R, Török N, Szalardy L, Plangar I, Szolnoki Z, et al. (2013) Association of vitamin D receptor gene polymorphisms and Parkinson's disease in Hungarians. Neuroscience Letters 551: 70-74.

136. Smolders J, Damoiseaux J, Menheere P, Tervaert JW, Hupperts R (2009) Association study on two vitamin D receptor gene polymorphisms and vitamin D metabolites in multiple sclerosis. Annals of the New York Academy of Sciences 1173(1): 515-520.

137. Mazdeh M, Ghafouri-Fard S, Hatami M, Eftekharian MM, Ganji M, et al. (2018) Expression analysis of vitamin D signaling pathway genes in epileptic patients. Journal of Molecular Neuroscience 64(4): 551558.

138. Kalueff AV, Minasyan A, Keisala T, Kuuslahti M, Miettinen S, et al (2006) Increased severity of chemically induced seizures in mice with partially deleted Vitamin D receptor gene. Neuroscience letters 394(1): 69-73

139. Holló A, Clemens Z, Kamondi A, Lakatos P, Szűcs A (2012) Correction of vitamin D deficiency improves seizure control in epilepsy: a pilot study. Epilepsy \& Behavior 24(1): 131-133. 
Chis work is licensed under Creative

(C) (i) Commons Attribution 4.0 License

BY DOI: 10.19080/NAPDD.2021.05.555672

\section{Your next submission with Juniper Publishers} will reach you the below assets

- Quality Editorial service

- Swift Peer Review

- Reprints availability

- E-prints Service

- Manuscript Podcast for convenient understanding

- Global attai nment for your research

- Manuscript accessibility in different formats

( Pdf, E-pub, Full Text, Audio)

- Unceasing customer service

Track the below URL for one-step submission https://juniperpublishers.com/online-submission.php 